\title{
SYMPOSIUM ON TWAIL PERSPECTIVES ON ICL, IHL, AND INTERVENTION
}

\author{
SELF-REFERRING TO THE INTERNATIONAL CRIMINAL COURT: \\ A CONTINUATION OF WAR BY OTHER MEANS
}

\author{
Parvathi Menon*
}

Weak sub-Saharan African states use international law and its institutions to legitimate their actions and delegitimate their internal enemies. In this essay, I argue that during internal armed conflicts, African states use international criminal law to redefine the conflict as international and thereby rebrand domestic political opponents as international criminals/enemies who are a threat to the entire community. This in turn sets the stage for invoking belligerent privileges under international humanitarian law (IHL).

The premise of this essay is that international criminal law's organization around the state makes it easier for African states to mobilize international criminal law against their internal enemies. Given that most conflicts in the African context involve both state and nonstate actors and that the Office of the Prosecutor (OTP) of the International Criminal Court (ICC) is unable to carry out investigations without the support of the state concerned, self-referrals to the ICC play out the structural biases of the law and its institutions. Whether it is because of the "gravity" of the crimes committed by the armed opposition groups or the strategic maneuvering by states, there is no doubt that the ICC approaches individual criminal responsibility differently when it comes to self-referrals.

\section{Self-referrals to the ICC: Continuation of War by Other Means?}

The experience of the ICC sheds light on the interactions between weak African states and international law. Certain African states, like Sudan, have resisted the ICC for its promotion of Western liberal democratic ideals by using the principle of complementarity: the rule that the Court can take a case only if the state concerned is "unable or unwilling" to try the same actions domestically. Other states, like Uganda1, the Democratic Republic of Congo (DRC) ${ }^{2}$, the Central African Republic (CAR) ${ }^{3}$, Cote d'Ivoire ${ }^{4}$ and Mali5 in subSaharan Africa, have used the trigger mechanism of "self-referrals" to the ICC to induce judicial recourse against their "enemies" —opposition/rebel groups—in an effort to increase the state's international reputa-

* Research Fellow, Max Planck Institute of Procedure Luxembourg.

Originally published online 17 March 2016.

${ }^{1}$ ICC, Press Release, President of Uganda refers situation concerning the Lord's Resistance Army (LRA) to the ICC (2004).

2 ICC, Press Release, Prosecutor receives referral of the situation in the Democratic Republic of Congo (2004).

${ }^{3}$ ICC, Press Release, Prosecutor receives referral concerning Central African Republic (2005).

${ }^{4}$ Présidence de la République de Côte d'Ivoire, Letter to the President of the International Criminal Court (Dec. 14, 2010).

5 ICC, Press Release, ICC Prosecutor Fatou Bensouda on the Malian State referral of the situation in Mali since January 2012 (2012). 
tion and the legitimacy of its military operations. For example, in July 2012, the Malian State referred ${ }^{6}$ the situation in Mali to the ICC to investigate the crimes committed by "various armed groups," which the Court's report ${ }^{8}$ demonstrates were comprised mainly of the MNLA (National Movement for the Liberation of Azawad), the AQIM (Al Qaeda in the Islamic Maghreb), and Ansar Dine, suggesting a pre-determination of who the criminals were. Similarly, Nouwen and Werner ${ }^{9}$ demonstrate how Uganda used the self-referral as part of its military strategy and international reputation campaign, when the government knew that it was unlikely to be victorious if it declared war on Sudan to force it to withdraw support to the Ugandan rebels, the Lord's Resistance Army (LRA). African states are also relying on the referrals to deflect international focus from human rights violations committed by their military forces. ${ }^{10}$ An examination of the preliminary investigation reports in situations that have reached the ICC through self-referrals highlight a disturbing trend of charges only against leaders of armed opposition groups. It can be seen that African states use the Court to delegitimize their enemies, thus legitimizing the government's military approach against the "uncivilized"11 rebels.

While Africa has been called the guinea pig for post-Cold War humanitarianism, weak African states are finding it increasingly useful to employ the rhetoric of IHL to redefine other forms of violence as an armed conflict, as evident from a report by the International Committee of the Red Cross. ${ }^{12}$ In addition to creating grounds for legitimating their military operations and war crime prosecutions, such redefinition of political violence as an armed conflict has also been used as a ground to request external military intervention. For example, in 2012 the United Nations Security Council authorized ${ }^{13}$ a military intervention, at the repeated request of the Malian State, explicitly to assist the Malian armed forces against the violations committed by "various armed groups." Even if the request for military intervention creates the veneer of a postwar concern with the protection of civilians and the prosecution of those alleged to have committed the impugned crimes, a closer look reveals the underlying political nature of international criminal law, of the self-referrals, as war by other means.

My claim is that the political character of the Court must be understood and acknowledged in order to fully gauge the political meaning of its judicial interventions. Despite multiple critiques, the OTP has adopted the policy of welcoming self-referrals. These self-referrals are a means to deal with a skeptical international community. They also allow the OTP to pacify its sceptics and respond to the pressure to open investigations, thus justifying the ICC's existence, as Nouwen and Werner persuasively argue. Self-referrals are also a way to assuage the fears of states about the use of the proprio motu power, and have further been viewed as a mechanism for obtaining the co-operation of the relevant state in investigation and enforcement, crucial areas in which the ICC lacks competence and resources. States tend to self-refer situations in an attempt to obtain legitimacy in the international arena and domestic political mileage against their opponents. This observation is buttressed by the fact that the OTP has, to date, not investigated the government of any self-referring state, but has concentrated on members of rebel groups alone. Additionally, in some situations, self-referrals also

${ }^{6}$ Government of Mali, Referral Letter (2012).

${ }^{7}$ ICC, Press Release, ICC Prosecutor opens investigation into war crimes in Mali: "The legal requirements have been met. We will investigate" (2013).

${ }^{8}$ OTP, Situation in Mali: Article 53(1) Report (2013).

${ }_{9}$ Sarah M. H. Nouwen \& Wouter G. Werner, Doing Justice to the Political: The International Criminal Court in Uganda and Sudan, 21 EuR. J. INT'L. L. 941, 951-953 (2010).

${ }^{10} \underline{I d}$. at 950 .

11 Antony Anghie, Finding the Peripheries: Sovereignty and Colonialism in Nineteenth Century International Law, 40 HARV. INT'L L.J. 1 (1999).

12 ICRC, NON-INTERNATIONAL ARMED CONFLICTS (2012).

${ }^{13} \underline{\text { SC Res. } 2085}$ (Dec. 20, 2012). 
give rise to the classic "peace v. justice" debate. Here, the Ugandan case will serve as a prime example of the ICC investigations perhaps exacerbating the conflict, ${ }^{14}$ in contrast to the current conflict in Mali and CAR as situations where "war" between the state and its opponents is continued in the form of a self-referral to the ICC.

Serving or Targeting Civilians?: Blurring the Civilian-Combatant Distinction

While African states have repeatedly taken a clear stand against the impunity of their leaders, an objective that the ICC's involvement could be perceived as significantly advancing, the loudest outcries against the Court were with respect to the two cases that were initiated against President Bashir of Sudan and the continuation of charges against Uhuru Kenyatta of Kenya, who was elected while charged in The Hague. Selfreferrals, on the other hand, enabled the states to demonstrate their desire to prosecute criminals, whilst reinforcing the superior role of the state vis-à-vis a nonstate entity through the responses of the Court.

Through their interpretation of IHL's core distinction between civilians and combatants, weak states like Uganda, DRC, Mali and more recently, CAR, treat the members of their opposition groups as unlawful combatants, making them targetable and prosecutable for war crimes under the Rome Statute. As nonstate armed groups possess neither the de jure privilege of a combatant nor the immunity of a civilian, states can rely on the membership of individuals in such groups to justify carrying out "legitimate operations" against them, often labeling them "enemies" and more recently, "enemy combatants."

In these African conflicts, the differing levels in rights and privileges afforded to states and nonstate parties under IHL establish an asymmetry between them. Lacking the prospect of both combatant privilege and civilian immunity, nonstate operatives exist on a continuum between civilians and combatants. The difficulty that state forces had in distinguishing the increasing number of nonstate actors (terrorists, rebels, insurgents, military contractors) from the civilian population led to the International Committee of the Red Cross' (ICRC) Interpretive Guidance on Direct Participation in Hostilities in 2009. The ICRC developed this Guidance in response to claims by state actors that relying solely on direct participation in hostilities (DPH) to determine permissible targets advantaged rebel groups. While the ICRC's Guidance states that DPH makes members of nonstate armed groups targetable based on their membership in such groups, on the ground that it amounts to a continuous form of civilian participation in hostilities (also called continuous combat function), African states were actually relying on membership-based targeting long before 2009 to suppress their political opponents. For example, the Ugandan government commenced a controversial military operation in 1990 to wipe out LRA rebels, which included forced displacement and internment camps housing millions of Ugandans. ${ }^{15}$ Similarly, in 2012, the Malian government, for the first time explicitly called for international military support against rebels. That year, alongside French forces, the Malian government initiated Operation Serval against Islamist and Tuareg rebels. This operation included extrajudicial killings of those suspected to be rebels, according to Amnesty International reports. ${ }^{16}$ In March 2014, with the support of the ICRC and African peacekeeping forces, the Malian government designated "anti-Balaka" rebels in CAR as enemy combatants. ${ }^{17}$

The foregoing examples demonstrate that even if it is an arduous task to distinguish enemy combatants from lawful combatants or civilians taking direct part in hostilities from other civilians, in order to determine

\footnotetext{
14 Adam Branch, Uganda's Civil War and the Politics of ICC Intervention, 21 ETHICS \& INT'L AFF. 179, 183-185 (2007).

15 International Crisis Group, NORTHERn Uganda: UndERSTANDING AND SOlVING THE CONFLICT 2 (2004).

16 Amnesty International, Mali: Civilians BeAr the Brunt of CONFlict, Amnesty InTERnATIONAL (2012).

17 AFP, CAR: African peacekeepers to treat 'anti-balaka' as enemies, AFrICA REV., Mar. 26, 2014.
} 
who can legitimately be targeted, detained, or prosecuted, states treat these distinctions as if they were clear and carry out operations as if war were justified everywhere, all the time. African states rely on the distinction to legitimately use force, target, or suppress opposing forces; and, further, seek external military and/or judicial intervention to establish the international legitimacy of such actions, adding credibility to the distinction itself.

The uncertainty that surrounds several aspects of the concept of DPH makes this area of the law one that merits close examination. The need for clarity is obvious, given the serious consequences that result from unlawful participation and the danger to innocent civilians posed by unlawful combatants. Taking direct part in hostilities is usually taken to mean to engaging in a specific attack or attacks on an enemy combatant or object during a situation of armed conflict. The ad hoc International Criminal Tribunal for the Former Yugoslavia (ICTY) in Prosecutor v. Krnoljelac stated:

An "attack" can be defined as a course of conduct involving the commission of acts of violence. The concept of "attack" is distinct and independent from the concept of "armed conflict". In practice, the attack could outlast, precede, or run parallel to the armed conflict, without necessarily being a part of it. $^{18}$

The jurisprudence of the ad hoc International Criminal Tribunal for Rwanda (ICTR) indicates that there is no substantive difference between the terms "active" and "direct." In its Akayesu judgement, the Trial Chamber found that these terms should be treated synonymously. 19 The ICC also adopted a broad definition of active participation in hostilities for the purpose of Article 8(2)(e)(vii) of the Rome Statute in prosecuting Thomas Lubanga, who took no active part in hostilities. ${ }^{20}$

\section{"Othering" Within the Boundaries of a State}

Whereas Third World Approaches to International Law (TWAIL) scholars tend to study the relationship between international law and Africa as one of resistance, participation, or acquiescence, my premise is that attention is also needed to responses previously attributed to Western states, like complicity and exploitation. In keeping with Judith Butler's account of the oppression and exclusion of the other, ${ }^{21}$ the postcolonial state, described in this context as a weak state, can be understood as suffering from a predisposition to reproduce the patterns of exclusion that are core to the reproduction of the self and the other. While the self/other distinction conventionally concerns the West's "othering" of the Third World or the Third World's selfdefinition as the "other," it should also concern an internal "othering" by the bourgeoisie within the thirdworld state-an "othering" that has been of only peripheral interest to TWAIL scholars. The self/other distinction relied upon by TWAIL scholars has been with regard to other types of asymmetrical conflicts like America's War against Terror and colonial wars, with lesser regard for situations that expose internal structural inconsistencies.

One of TWAIL scholars'22 core criticisms of international law is its perpetuation of the structural problématique of colonialism through modern institutional power hierarchies. I find much merit in the argument that

${ }^{18}$ Prosecutor v. Krnojelac, Case No. IT-97-25-T, Judgment, para. 54 (Int'l Crim. Trib. For the Former Yugoslavia Mar. 15, 2002).

${ }^{19}$ Prosecutor v. Akayesu, Case No. ICTR-96-4-T, Judgment (Sep. 2, 1998).

${ }^{20}$ Prosecutor v. Lubanga, ICC-01/04-01/06, Judgment (Mar. 14, 2012).

21 See Judith Butler, Bodies That Matter (2011), Gender Trouble (1991), Excitable Speech (1997) and her article Sovereign Performatives in the Contemporary Scene of Utterance, 23 CRITICAL INQUIRY 350 (1997).

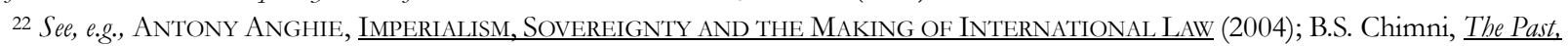
Present and Future of International Law: A Critical Third World Approach, 8 MELB. J. INT'L L. 499 (2007). 
these structures were designed to subordinate the Third World. The ICC is one such organization that has come under scrutiny for targeting African states ${ }^{23}$, whilst ignoring the crimes of other parts of the world. Despite that oft-repeated critique by the African states, to view the Court as the only exploiter is to miss an important dimension.

My analysis of self-referrals demonstrates that the Third World articulates its agency in a legal form. But the structural asymmetry of this legal form, which gives the power to states and not to nonstate actors, enables the embedded logic of the "dynamic of difference" to be reproduced internally. The assertion in Asad Kiyani's essay in this symposium that ICL's selectivity is equally manifested internally and internationally is interestingly argued through a comparison of the self-referral by Uganda with the Security Council referral of Darfur. ${ }^{24}$ The key distinction between "internal othering," as argued here, and Kiyani's description of "internal dissension" is that his analysis is from an institutional point of view, focusing on the selectivity of International Criminal Law and its institutional apparatuses, whilst this essay analyzes selectivity from the angle of the state towards its own people internally.

The concept of self-referrals has also been criticized ${ }^{25}$ as contravening the ICC's espousal of positive complementarity. ${ }^{26}$ The expectation that the domestic systems would handle the bulk of the cases had turned into an (unwritten) obligation, according to which the ICC would be treated as the court of last resort only if the states demonstrated genuine incapacity. Self-referrals seemed to absolve the states of such obligation, enabling its externalization.

While both critiques, of case selection and the contravention of the principle of complementarity, are of a procedural character, the structural shortcomings of the ICC require examination in order to understand the concept of what is called "internal othering." Relying on Antony Anghie's concept of a "dynamic of difference," TWAIL adherents argue that the principle of complementarity enshrined in the Rome Statute was not, as it often appears, a compromise meant to protect state sovereignty, but a technique to perpetuate the "civilized/uncivilized" dichotomy between the West and the Third World. Yet, they completely ignore the other side of the coin; namely, the creation of that same dichotomy within the so-called "uncivilized" world.

\section{Conclusion}

My contention is that the doctrinal and institutional terrains of international law today are as much a tool of the weak as the strong, causing the reproduction of the self/other distinction within weak states. While TWAIL methods could be useful for a critical understanding of international criminal law's origin and modes of operation, in theorizing the relationship between Africa and international law, TWAIL scholars fail to push far enough to take into account an important dimension: the reproduction of the subordination within thirdworld states demonstrated here in the context of the ICC. Unlike many third-world states, states like Mali, Uganda, DRC and CAR are constantly threatened by coups, "de-democratization" and cycling between an apparent democracy and a failed state. Wars waged internally in African states tend to destabilize them, thus making the "communication of legitimacy" an important political tool wielded through purely legal means. Similarly, states rely on the diversity within the meaning of terms like "combatants" in order to delegitimate their

23 See Mahmood Mamdani, Darfur, ICC and the New Humanitarian Order: How the ICC's "Responsibility to Protect" Is Being Turned into an Assertion of Neo-Colonial Domination, PAMBAZuKa News, Sep. 17, 2008.

24 Asad G. Kiyani, Third World Approaches to International Criminal Law, 109 AJIL UnBound 255 (2016).

${ }^{25}$ Darryl Robinson, The Controversies over Territorial State Referrals and Reflections on ICL Discourse, 9 J. INT'L CRIM. JUST. 355(2011).

${ }^{26}$ Payam Akhavan, Self-referrals before the International Criminal Court: Are States the Villains or the Victims of Atrocities? 21 CRIM. L.F. 103 (2010). 
enemies - also a strategic tool to further their own legitimacy. Treated as forgotten crises and forgotten states, weak states caught in internal conflicts on the periphery of international law are using international law to advance their interest in a concerted manner today. They are, I believe, through such institutional mechanisms as the ICC, also contributing to the jurisprudence of international law, contrary to the claims made by TWAIL scholars. As much as I agree with the tenets of TWAIL scholarship, I think it defeats its own thesis when it treats all alike, all as equally subjugated, even within the Third World. 